\title{
SCIENCE. KNOWLEDGE. PHILOSOPHY
}

\author{
Aldona MUSIAE-KIDAWA \\ Politechnika Śląska, Wydział Organizacji i Zarządzania; aldona.musial-kidawa@ polsl.pl, \\ ORCID: 0000-0001-9525-6348
}

Purpose: The publication discusses the mutual relations between philosophy, science and cognition.

Methodology: The main method is the analysis of the subject literature.

Findings: The article discusses issues of epistemological nature, describes the mechanism that enables cognition as both an experience and an act of will.

Social implications: For European culture, the concept of truth is fundamental, and can be interpreted as a practical value in life or as a never-ending search for the meaning of human existence.

Originality/value: The result is recognition that science and philosophy, both cognitive categories ultimately provide the starting point for research on the status of man as a being above the biological and for research on his moral condition.

Keywords: truth, cognition, freedom, man, morality.

Category of the paper: Conceptual paper, General revive.

The work of Leszek Kołakowski is concentrated around a man whose presence in culture, science, cognition and philosophy shapes the standards of civilization development understood broadly as the humanistic heritage of humanity, as well as in a slightly narrower dimension as a degree of mastery of the forces of nature. These two orders, both the idea of searching for the meaning of human existence and the idea of mastering and cognition of the laws of nature are the intellectual consequence of searching for an answer to the question about the nature of human existence and the limits of human cognition. Between these two activities, exploring and revealing the mystery of the transcendent nature and nature of the biological world, the presence and fate of man in the world is determined in a shaky equilibrium.

Contemporary European culture focuses on the determination of the real condition of man, especially from the perspective of the idea of mastering (cognition) nature and the idea of searching for the sense of human existence. The development of science was a process of emancipation of secular reason in opposition to traditional metaphysical and religious considerations (Kołakowski, 1987). The progress of modernization taking place through affirmation of the principles of empiricism, expressing the interpretation of the experiment 
under the conditions of mathematical methods and quantitative experience, constituted the perspective of technological values accepted as superior in technocratic culture. Philosophical empiricism, by setting the limits of perception, justified the need to accept the indications of human rationality, using methods appropriate to natural sciences. On the other hand, the thought of rationalism in science built up a biological and intellectual opposition in the life of an individual (Kołakowski, 1966). The biological dimension of life has sanctioned human existence through genetically regulated behavioral mechanisms, including cultural symbolism, which is the process of elevating the primordial drives that realize the genetic determinism of the layer of existence. This perspective revealed the position of culture remaining beyond the possibility of expressing its autonomy (Kołakowski, 1991) and defined the condition of science as a field of life related to the utilitarian values of reality, values that are translated primarily into the degree of mastery of natural phenomena, i.e. securing the conditions for survival. As a consequence, technological utilitarianism revealed the context of the legitimacy of scientific knowledge independent of transcendental forms of cognition and the value of truth constituted in European culture sanctioning the a priori constitution of truth referring to biological, psychological and social-historical conditions. The relative legitimacy of scientific knowledge determines the criteria of moral values that make up the nonempirical world order, because science, as a cultural fact that shows reality in mediated perception, reveals the world that: "does not make sense and does not make a difference between good and evil, a world in which reality is pointless and there is no other hidden reality behind it" (Kołakowski, 1999). Kolakowski points out that the empirical construction of knowledge negating the notion of truth as an immanent necessity defines relativistic consequences, so that cognition, remaining a feature of human behavior, accepts the reality of the world related to the pragmatically interpreted sense. The philosopher points to Nietzsche's Ultimum, The Ultimate World which, while exhausting itself, exists beyond the objective certainty of good and evil, establishing the reality of extreme ethical relativism. Kolakowski strongly opposes the ethical nihilism justifying the possibility of random disposal of norms and principles (in the transcendental sense, which condition the moral value of human life), because: "if I am the creator of the rules, there is no reason for me to feel guilty because I have violated them, or I can change them in one moment from the point of view of my personal interest" (Kołakowski, 1999). By negating the biological perspective of cognitive activity and the certainty of knowledge conditioned by practical needs, the philosopher reveals the destructive implications of naturalism and empiricism from the perspective of constitutive acts of autonomous cognitive values for human reality. The categories of the notions of absolute truth, metaphysical certainty and synthetic courts a priori make the truth tout court present, eliminating the notion of truth as expressed through compliance with the acceptance experience, because the sense of acceptance of something is not contained in the dichotomous division of "truth-falteration". The idea of an overbearingly certain truth is a construction of the perception of the world existing in the transcendental value, reveals the essence of "the world as it must be". This perspective, 
by defining the non-relative legitimacy of truth, not only identifies the present reality of the world, but also reveals "compatibility with the world as it really is" (Kołakowski, 1991). Kolakowski stresses that the absolute nature of scientific criteria is a justification for the idea of certainty expressed by the principle of acceptance focused on potential usefulness, because: "Science doesn't need anything else" (Kołakowski, 1991). The consequence in the dimension of social life remains the construction of a human community organized around rational rules of behavior, a community affirming values that are a reference to the egoistic system of conditional reflexes. The community of atomized individuals endowed with intelligence justifies the need for the institutions of the order of rights and obligations, including the enforcement of rules, but their legitimacy is revealed beyond the experience of transcendence, while empirically conditioned moral norms sanction the possibility of human creativity expressed in exceeding the limits of truth and falsehood, good and evil, fiction and reality. The philosopher, pointing out that the search for certainty in an empirically understood perspective defines the concept of truth, concentrating only on the improvement of technical skills that allow to identify the world order, also points to the problem of practically grounded certainty from the perspective of the opposing high degree of theoreticization of scientific knowledge. Acceptance of technical knowledge determined by practical considerations is beyond the reference of "big turning points", essential in the history of knowledge, because practical justification cannot explain the essence of "turning points" especially because: "if not expected to extract from this knowledge something more than practical use, if not searched for truth and certainty as intrinsic values, a technically fruitful science would not be created" (Kołakowski, 1991). In his text Truth and truthfulness as values of culture (Kołakowski, 2000), Kolakowski points out that from this perspective, the notion of truth in a coherent relation to theoretically grounded scientific knowledge is an autotelic value of the quality of knowledge without any reference to the technological efficiency of knowledge. The philosopher points out that, in this sense, the classical definition of the Truth Veritas est adaequatio intellectus et rei is valid "irrespective of the utilitarian criteria for the recognition and rejection of claims" (Kołakowski, 2000). He especially notes the issue of scientific deontology, which determines the absolute application not only of strict justification, but, above all, of a real belief in the existing conformity of the statement with the intention, so that the credibility of the justification of scientific knowledge is constituted in relation to the moral credibility and responsibility of the scientist. In scientific work and cognition expressing "the demand for integrity, mental ruthlessness, attachment to 'truth' over and above attachment to hypothesis, the demand for good faith" (Kołakowski, 2000) realizes the value of truth as the "autotelic value of the quality of knowledge".

Kolakowski, noting that the search for certainty shapes the constitutive value of European culture, determining its continuity of updating, points to the trend of transcendental philosophy constituting an opposition to European skepticism and relativism, positions that exemplify the pragmatic interpretation of cognition, as well as positions that negate the Platonic identification 
of the difference between doxa and episteme. The contraceptional intellectual tradition of European philosophy focuses on the search for an indisputable basis for cognition and absolute truth overcoming nihilistic skepticism conditioned by the randomness of cognition of the relativizing content of cognition through the interpretation of history and psychology. He emphasizes Husserl's philosophical concept sanctioning the notion of truth in relation to the transcendental basis of certainty as a condition for intellectual and moral necessity in the structure of the world known unconditionally and reliably. Kolakowski recognizes that, according to Husserl, the consequence of phenomenological reduction is the transcendental ego, defined as cognitively primal consciousness constituting an objective reality, which is the subject of her thoughts. Furthermore, the transcendental reduction reveals a nonempirical ego, identified as a pure subject of cognition, that is: "something that does not have properties usually attributed to psychological subjects, but retains an intentional reference to its subject" (Kołakowski, 1991). Phenomenological reduction is the basis for the interpretation of the mystery of the sense of knowledge and the world of values, shaping the consciousness of certainty based on the original intuition in cognition and realizing the possibility of overcoming the claims of epistemological and ethical relativism. Kolakowski stresses that the necessity of searching for cognitive certainty places Husserl's philosophical concept in total opposition to psychological certainty, which determines naturalistic, positivistic and antimetaphysical options, options indicating the quality and status of human condition, because: "philosophers constantly sought a third solution, a source of truth and order, which would be independent from both God and empirical criteria. Although these explorations were important in the history of culture, they were doomed to failure in the sense in which they were intended. Most of them were undertaken in the hope that this third way could be rational in the sense in which modern science makes claims to rationality" (Kołakowski, 1984). Kolakowski states that the phenomena of culture based around the technological mastery of the forces of nature determine the achievement of a high level of civilization, but the affirmation of the technological values of culture is only the validation of the certainty of practical knowledge. Technological premises constitute the notions of science and science as an organized cognitive process shaped by established logical and mathematical principles, which are a condition for determining the reality in the interpretation of scientific cognition. The pragmatic interpretation of cognition excludes the level of intrinsic values that are the foundation of understanding European culture, and consequently the perception of the difference between the search for truth and certainty in a utilitarian sense is defined as invalid, because according to the theory of cognition of scepticism: "what we really know are useless single perceptions whose ontological meaning we are not allowed to ask about" (Kołakowski, 1991). Meanwhile, the search for certainty expressed by reference to transcendental forms of cognition is a much wider range of human perception than merely scientific cognition, exemplified by the level of technological achievements. The search for certainty is not only determined by the practice of social life and 
the degree of mastery of natural forces, although a priori certainty is a condition for technological status, for science in general.

The search for truth determines the above-empirical, non-utilitarian status of questions concerning the humanity of the human being, affirmation of the perspective that there is a perfect meaning of the notion of man as a rational subject, remaining in the dignity of his dignity to every other equal. This significance, therefore, strengthens the position of man in human reality (Kołakowski, 1984), so that man is a self-contained goal, thus expressing his opposition to the random utilitarian criteria that each time identify the principle of humanity. Kolakowski indicates the area of philosophy that makes the sense of human existence present and the understanding of the world through the transcendental consciousness that constitutes the necessary structures of the world, so that truth is a value for itself, independent of our acts of perception, and thus the identified truth negates generic relativism, accepting the existence of ideal meanings (its idea). (Kołakowski, 1991). The philosopher notes that: "The idea of epistemology based on science is absurd" because philosophy as a reflection on understanding the world, striving to know its essence, realizes the love of wisdom as a value in confrontation with a critical situation which cannot be met by wisdom in a common, non-reflective sense (Kołakowski, 1989). From this perspective, the "seriousness of the philosophical tradition" explicitly expresses the reasons for the omni-explanatory picture of the world that reinforces the certainty of the existence of truth, because: "the constant inability to answer the fundamental questions that the Universe and the human world are asking us is intolerable" (Kołakowski, 1999). Philosophy, being the highest form of cognition, legitimizes relationships between temporal and unchangeable beings, relationships that allow to discover the sensible order of the world and the value of true knowledge (episteme) about the nature of reality as the ultimate source of certainty. Kolakowski points out that philosophy, using the category of true reality (time and unchangeable), makes it possible to formulate an ideal of conduct that conditions the quality of human life and human solidarity. The lack of satisfactory solutions to the problem of the essence of our being not only does not constitute a threat to the survival of man in a world of changing things perceived by the senses, but it also makes man's human status a reality, strengthening his privileged position as the rational subject which determines this continuity of existence, for it is: "'if to be' was not 'to do something' and the world was meaningless, not only would we never be able to imagine that it is different, but we would not even be able to think that 'to be' is not really 'to do something' and the world is meaningless" (Kołakowski, 1990). The total satisfaction of the desire to understand the world in consequence limits the perspective of human subjectivity. As the Philosopher underlines, the search for the epistemological absolute, the source of certainty, remains beyond the possibility of fulfillment, but he designs a desire to search for the sense of the world exceeding scientific rationality, the world excluding the category of the randomness of existence (Kołakowski, 1994). The philosopher, pointing out that the source of the development of science is the experience of the difference between the essence and the phenomenon, sees at the same time that the 
awareness of this difference reveals the imperfection and fragility of the human condition, which is the perspective of strengthening the human perception, so that it reveals the ability to distinguish between "adventurous and necessary, between what is acceptable and what is certain, between relative and absolute, finite and infinite" (Kołakowski, 1991). Kolakowski emphasizes that scientific cognition, by identifying the "temporary truth" referring to the relative results of the examined reality, is in opposition to philosophical cognition using the notion of "absolute truth" referring to objective reality, reality excluding the principle of verification. The philosopher states that philosophical cognition is an understanding of interpretation that refers to the study of senses, so as to "awaken sensitivity to the sense of actions that go beyond philosophy and scientific thinking" (Kołakowski, 1994). Kolakowski points to the self-awareness of philosophy implying the knowledge of the sources constituting the basis for transcendental hopes which are still being renewed in human history, because "the annulment of the epistemological question and the metaphysical question cannot take place once and for all, the sense of these questions is renewed every time and refreshed in subsequent historical situations" (Kołakowski, 1991). This perspective determines the philosophy of the necessity to identify historical reasons, even though the function of philosophy within the limits of its own rigours remains beyond the reference to these reasons, because as he notes: "exceeding the rigours of philosophy is a faith" (Kołakowski, 1991).

Kołakowski recognizes that the perception of aesthetic order in a chaotic universe, revealed through the intuition of beauty, intuition defining the form of consciousness of one's own existence, remains a special constitution of human existence. The experience of beauty as a metaphysical reflection determines the possibility of identifying one's own situation and thus constitutes an existential act, the consequence of which is the desire to realize a permanent internal harmony in becoming a human being. The intellectual category of human reality, beauty, allows us to identify the presence of man through the opposition contained in the expression "intelligent animal", the opposition between the biologically situated property of existence and the transcendently related quality of perception. Overcoming this opposition reduces not only a certain degree of emotional alienation of man from organic nature, but above all creates man as an autonomous reality defined by the ability to realize the intentionality of acts and experiences. This perspective of the meaning of beauty constitutes the idea of humanity, an idea that overcomes all forms of reification, impersonal forms of existence, an idea that assumes a permanent and authentic identity of the way of existence in the world. Humanity as an expression of emancipation in the face of natural forces implies the uniqueness and uniqueness of every human being in pursuit of transcendent values and goals. The metaphysical sense of the meaning of beauty self-realizes man through his striving to express, create, and engage: "A man's aesthetic is what makes him directly what he is" (Kierkegaard, 1976). Kierkegaard's thought refers to the ancient meaning of beauty as a measure of the assessment of moral phenomena. In his article Myth in the World of Values, Kolakowski points out that the world of values (art manifests the idea of beauty) is a mythical 
reality, transcending absolutely all possible experience, including the experience of humanity: "Myths teach us that something is just a value, myths are inevitable if human society is to exist" (Kołakowski, 1994).

\section{References}

1. Armesto, F.F. (2000). Historia prawdy. Poznań: Zysk i S-ka.

2. Kamiński, S. (1989). Naukowa, filozoficzna i teologiczna wizja człowieka. In: Jak filozofować. Lublin: KUL.

3. Kierkegaard, S. (1976). Albo - albo, t. 2. Warszawa:, PWN.

4. Kołakowski, L. (1966). Filozofia pozytywistyczna. Warszawa: PWN.

5. Kołakowski, L. (1984). Czy diabeł może być zbawiony i 27 innych kazań. London: Aneks.

6. Kołakowski, L. (1987). Jeśli Boga nie ma... London: Aneks.

7. Kołakowski, L. (1989). Pochwała niekonsekwencji. Warszawa: Aletheia.

8. Kołakowski, L. (1990). Horror metaphysicus. Wraszawa: Res Publica.

9. Kołakowski, L. (1991). Husserl i poszukiwanie pewności. Warszawa: Aletheia.

10. Kołakowski, L. (1994). Obecność mitu. Wrocław: Wydawnictwo dolnośląskie.

11. Kołakowski, L. (1997). Bergson. Warszawa: PWN.

12. Kołakowski, L. (1999). Moje stuszne poglądy na wszystko. Kraków: ZNAK.

13. Kołakowski, L. (2000). Kultura i fetysze. Warszawa: PWN.

14. Kołakowski, L., Pomian K. (1965). Filozofia egzystencjalna. Warszawa: PWN.

15. Russell, B. (1997). Konflikt między techniką a naturą ludzką. In: Władza i jednostka. Warszawa: Książka i Wiedza.

16. Tischner, J. (2002). Spór o istnienie człowieka. Kraków: ZNAK.

17. Tischner, J. (2006). Filozofia dramatu. Kraków: ZNAK. 